OPEN ACCESS

Vol. 8, No. 2, Oktober, 2020

Page. $44-54$

DOI: https://doi.org/10.21107/jaffa.v8i2.7449
JOURNAL OF AUDITING, FINANCE, AND FORENSIC ACCOUNTING

E-ISSN: 2461-0607 ISSN: 2339-2886

https://journal.trunojoyo.ac.id/jaffa

\title{
Effect of Corporate Governance and Corporate Social Responsibility on Financial Performance
}

Indah Maha Sari; Rita Anugerah; Azwir Nasir

Master of Accounting Program, University of Riau, Indonesia

\section{Article Info:}

Received: 06 April 2020

in revised form: 30 July 2020

Accepted: 30 September 2020

Available Online: 28 Agustus 2020

\section{Keywords:}

Independent Commissioner, Audit

Committee, Corporate Social

Responsibility, Financial

Performance

\section{Corresponding Author:}

Email: indahmahasari8@gmail.com
Abstract; This research was conducted to find out effect of independent commissioner, audit committee, and corporate social responsibility on financial performance at Index Kompas 100 in in Indonesia Stock Exchange period 2016-2018. Index Kompas 100 company has high market capitalization value, so it is suitable for use as a population. Samples were determined using the purposive sampling method. Research using multiple linear analyses. This research prove that independent commissioner, audit committee, corporate social responsibility have a influence on financial performance.

Abstrak; Penelitian ini dilakukan untuk mengetahui pengaruh komisaris independen, komite audit, dan tanggung jawab sosial perusahaan terhadap kinerja keuangan pada perusahaan Indeks Kompas 100 di Bursa Efek Indonesia periode 2016-2018. Perusahaan perusahaan indeks kompas 100 memilliki nilai kapatilisasi pasar yang tinggi, oleh karena itu sangat sesuai digunakan sebagai populasi dalam penelitian ini. Penentuan sampel menggunakan metode purposive sampling. Penelitian menggunakan metode analisis linear berganda. Hasil penelitian membuktikan bahwa komisaris independen, komite audit, dan corporate social responsibility memiliki pengaruh terhadap kinerja keuangan. 


\section{INTRODUCTION}

Financial performance is needed by the company to meet and evaluate the company's success rate based on the financial activities (Rudianto, 2013:189). For the company, maintaining and improving financial performance is an obligation, so that the company's shares remain interested to investors. The financial statements issued by the company are a reflection of financial performance. The phenomenon of financial performance occurred at PT. Garuda Indonesia, in 2018 financial statement PT. Garuda Indonesia recorded a net profit of USD 809.85 thousand or Rp. 11.33 billion. This figure increased compared to 2017, which suffered a loss of USD 216.5 million. The existence of these profits, one of which is caused by cooperation between PT. Garuda Indonesia and PT Mahata Aero Technology, related to the provision of connectivity services in aviation. The cooperation has value reaches USD 239.94 million, or Rp. 2.98 Trillion. These funds are still in the form of receivables, but have been recognized as revenue, so the company previously lost and then made a profit. Financial statement PT. Garuda Indonesia in 2018 caused problems, because two commissioners of PT. Garuda Indonesia, Chairul Tanjung and Dony Oskaria, objected to the recognition of revenue for the transaction agreement on the supply of connectivity services in aviation, this is because the results of the financial statements presented are not in accordance with the statement of financial accounting standards (soure: moneykompas.com).

PT. Garuda Indonesia is likely to ignore the application of the corporate governance principle, in preparing its financial statements. PT. Garuda Indonesia is suspected of manipulating and not being transparent in recognizing revenue, that should not be recognized, which resulted in financial performance looking good, but in fact the company suffered losses. This shows that, companies in Indonesia have implemented corporate governance, but its implementation has not been properly, maybe due to lack of understanding regarding the application of good corporate governance in the company, and can also be caused weak regulations governing corporate governance, so that opportunities arise for various fraudulent practices, resulting in losses for the shareholders. The existence of such cases is suspected, because the commissioner, through the audit committee does not ensure that the preparation of financial statements has been conducted in the general prevailing accounting principles. Independent commissioner as a supervising party to the company, and the function of the audit committee to ensure accountability of financial statements needs to be questioned.

Implementation of corporate governance in the company requires full commitment and consistency from various parties (shareholders, directors, employees and parties outside the company). Without high and consistent commitment, there is concern that the intention to implement corporate governance does not provide added value to the company. One obstacle to the implementation of corporate governance in Indonesia is the culture of coruption, colusion and nepotisme, which is very contrary to the principles of corporate governance (Effendi, 2016:208). Corporate governance is needed by companies to encourage the creation of markets that are efficient, transparent and consistent with applicable regulations. The implementation of good corporate governance does not necessarily make a company's shares become more liquid, but with the trust of investors, the public, creditors, the company is not difficult to find funding for expansion, and ultimately affect the movement of shares and improve the financial performance.

Corporate governance able to raise company's value, improve financial performance, mitigate risks, and can raise investor turst in the company (Newell \& Wilson, 2002). For investors, corporate governance is one of the valuations in investing, as well as, financial performance and growth potential, especially for emerging markets. Investors tend to avoid companies implementing bad corporate governance (McKinsey \& Company, 2002). The role of independent commissioners and audit committees in the implementation of corporate governance is needed, to maintain the credibility of the process of preparing financial statements, so that company supervision can be carried out properly.

The independent commissioners is the core of corporate governance, assigned to ensure the implementation of the company's strategy, oversee management in managing 
the company and require the implementation of accountability (Fadillah, 2017). The role of the independent commissioner oversees directors and advises directors on irregularities and business management that is not in line with company goals, and monitors the implementation and effectiveness of corporate governance practices. The independent commissioner can provide a view with a high degree of independence, which in turn will affect financial performance.

The effect of independence of commissioners on financial performance have a various conclusions. The results of study performed by (Mahrani \& Soewarno, 2018), (Saputra, 2018) and (Bintara, 2019) which states that independent commissioner has effect on financial performance. These results are different from the study performed by (Andriana \& Panggabean, 2017), (Zulfikar et al., 2017) and (Farida et al., 2018) which stated, that independent commissioners has no effect on financial performance.

In carrying out their duties the board of commissioners is assisted by several committees, one of them is audit committee. The audit committee functions, as a party that connects shareholders and the board of commissioners with management in overcoming oversight issues. The duties of the audit committee are assisting the commissioners to improve quality of financial statements and improve the effectiveness of internal audit and external audit. Supervision carried out by the audit committee can be done through a meeting conducted by audit committee. The audit committee through an audit committee meeting has effect on financial performance, because the higher frequency of meetings held, will increase the effectiveness of the audit committee in overseeing management. by holding regular audit committee meetings, the audit committee can prevent and reduce possibility of mistakes in management decisions.

The effect of the audit committee on financial performance have a various conclusions. The results of study performed by (Aryan, 2015), (Gabriela,2016) and (Orjinta \& Evelyn, 2018) which states that the audit committee have effect on financial performance. These results are different from the study performed by (Heriyanto \& Mas'ud, 2017), and (Mulyadi, 2017), which states that a meeting conducted by the audit committee has not effect on financial performance.

The existence of an independent commissioners and audit committee has a very important and strategic role in maintaining the credibility of the financial statement preparation process, as well as maintaining the creation of an adequate corporate supervision system and the implementation of corporate governance. As the function of the independent commissioners and the audit committee effectively, the control of the company will increase, thus management will be transparent in managing the company, which in turn improves the company's financial performance.

Beside financial performance and corporate governance, there is also a good management performance in the form of social relations with the surrounding environment through the implementation of corporate social responsibility. Nowadays, investors prefer to invest, in companies that have implemented corporate social responsibility. In Indonesia, the implementation of corporate social responsibility is an obligation to be implemented by the company, regulated in the limited liability companies law No. 40 of 2007. Through corporate social responsibility, it is expected to built effective communication and harmonious relationship between company and the surrounding community (Effendi, 2016:166).

The existence of corporate social responsibility, so investors can know the company's condition as a whole, not only from information related to the company's financial condition, but also externalities issues such as, social and environmental impacts arising from the company's economic activities (Lako, 2011: 13). The more disclosure of corporate social responsibility activities, this will increase the company's reputation, and can increase the price of shares and capital of the company is also getting bigger. The large capital can be managed by company, so that it will produce high profits and increase financial performance.

The low awareness of companies to disclose environmental and social problems, one of which can be caused by the weak regulation of limited liability company law No.40 of 2007 article 74 relating to corporate social responsibility, where there are no specific rules governing corporate criteria that are subject to corporate social responsibility obligations, what punishment are given to companies that violate corporate social responsibility obligations, minimum budgetary cost of corporate social responsibility costs that must be budgeted by the company (Solihin, 2008:166). So the 
assumption arises that it does not become a problem, if a company does not disclose corporate social responsibiliy. In fact, disclosure of social and environmental problems made by a company is a form of accountability of the company to the public and also as an effort to maintain the existence of the company in the community.

The phenomenon corporate social responbiliy, seen from the results of Research Center for Governance, Institutions, and Organizations of the National University of Singapore (NUS) Business School publishes, the results of the study explained that the quality of corporate social responsibility to 100 companies in four countries, namely Indonesia, Malaysia, Singapore and Thailand. The research results explained that Thailand became the country with the highest quality of corporate social responsibility implementation with a gained 56.8 out of a total of 100 and Singapore gained 48.8. While Indonesia scored 48.4 and Malaysia won 47.7. According to the research, companies in Indonesia have lower corporate social responsibility quality, compared to companies from Thailand.

Based on the research, the government and industry stakeholders have a role in ensuring sustainable corporate social responsibility reporting. It was considered as the main key to corporate governance. All this time corporate social responsibility disclosure report is need to imporve reputation company for stakehoder, that the company has a concern for the environmental social environment. Disclosure of corporate social responsibility by companies has been widely used by companies for various interests of the company itself. Not a few companies that provide forms of social responsibility only provide or increase profits. However, many companies are already aware of its importance reporting and disclosure of corporate social responsibility that provides good impact for company.

The effect of corporate social responsibility on financial performance have various conclusions. The results of study performed by (Ummah, et al., 2016), (Mahrani \& Soewarno, 2018) and (Maqbool \& Zameer, 2018), stated that, corporate social responsibility has effect on financial performance. These results are different from the study performed by (Siregar and Bukit, 2018) and (Mangantar, 2019) who stated that corporate social responsibility had no effect on the company's financial performance.

The application of corporate social responsibility is also one of the implementations of corporate governance principles, namely responsibility. Through the implementation of corporate social responsibility and corporate governance, companies are is expected to improve attention on environment, workplace conditions, company relations, society, social investment company, financial performance, access to capital, and enhance the company's reputation. If corporate social responsibility is implemented, so will be able to give guarantee to the stakeholders that the company has carried out good corporate governance. The impact of corporate governance and corporate social reponsibility on financial performance has a various conclusions, so researchers want to do research again, whether corporate governance and corporate social responsibility are able to affect on financial performance.

This research was conducted on the index kompas 100 company listed on Indonesian stock exchange. Index Kompas 100 company has high market capitalization value. Index kompas 100 company represent around $70-80 \%$ trillion market capitalization value of all shares listed on the Indonesian stock exchange. Market capitalization value has an important meaning for investors, because it is able to influence investor's interest to make it a portfolio instrument or not. In general, the greater the market capitalization value of a stock, then the more investor interest in the store, so it is suitable for use as a population this research and also as a reference for investors. Based on the background explantation, the researcher interested in conducting the research with the title "Effect of Corporate Governance and Corporate Social Responsibility on Financial performance".

\section{LITERATURE REVIEW AND HYPOTHESES DEVELOPMENT}

\section{Independent commissioner on financial performance}

Independent commissioner is part of company's board of commissioners, which has fulfilled the requirements of the Financial Services Authority Regulation (POJK) No. 33/POJK. 04/2014. Independent board of commissioners in the company, is a representative of independent (minority) shareholders and represents the interests of 
other investors. (Stiles \& Taylor, 2007), state that, the proportion of independent commissioners will increase the financial performance. (Wu, et al., 2009), stated that, independent commissioner have an influence on financial performance, according to the high-professionalism independent commissioner will produce objective decisions and create effectiveness in conducting supervision, so that the decision taken is not for the sake of certain parties. Mahrani \& Soewarno (2018) stated that, independent commissioners can minimize the agency issues arising between the board of directors and the shareholders. (Saputra, 2018), which states that, the independent commissioners is the core of corporate governance assigned to ensure the implementation of corporate strategy, to maintain management in managing the company and to require the enforcement of accountability. (Bintara, 2019), which states that proportion of independent commissioners has an influence on financial performance.

$\mathrm{H}_{1}$ : Independent commissioner has an effect on financial performance.

\section{Audit committee on financial performance}

Audit committee has a role in monitoring the process of financial reporting and internal control. Audit committee convene an auditory committee meeting conducted periodically. Financial Services Authority Regulation (POJK) No. 55/POJK.04/2015 concerning the Formation and Implementation Guidelines for the Audit Committee's Work states that the Audit Committee meets periodically at least 1 (one) time in 3 (three) months. According to (Beasly, 2004), Company's audit committee making mistakes in financial statements has a slight frequency of meetings, rather than the company's audit committee which does not make mistakes in financial reporting. (Aryan, 2015) stated that audit committee meetings playing important role to ensure the effectiveness of the audit committee. (Gabriela, 2016) states that a more active audit committee that meets frequently will be a more effective supervisory body compared to audit committees that rarely meet (considered inactive) less likely to monitor management effectively. (Orjinta \& Evelyn, 2018) stated that regular audit committee meetings can help mitigate the company's agency and information asymmetry issues, and provide fair and proper information to investors.

$\mathrm{H}_{2}$ : Audit committee has an effect on financial performance.

\section{Corporate social responsibility on financial performance}

Corporate social responsibility The responsibility of the company to participate in sustainable economic development, in order to improve the quality of life and the environment, which in turn will benefit the company itself, and society in general (the limited liability companies law No. 40/2007). According to (Aver \& Cadez, 2009) corporate social responsibility activities are well managed, not only will increase the satisfaction of the stakeholders but also leads to increased financial performance of the company. (Ummah, et al., 2016) stated that implementation of corporate social responsibility of the company will get a good image from stakeholders, the company will get the trust of stakeholders that the company can be responsible for the economic, environmental and social conditions of the company. (Mahrani and Soewarno, 2018) stated that, a good relationship between society and the company will create the support of the community affecting the company's survival. (Maqbool and Zameer, 2018) stated that corporate social responsibility can lower financial risk, so that the company has a minimum chance to experience bankruptcy, compared to companies that do not implement corporate social responsibility.

$\mathrm{H}_{3}$ : Corporate social responsibility has effect on financial performance

\section{RESEARCH METHODOLOGY}

\section{Research Overview}

The population of this research were index kompas 100 company listed on the Indonesian stock exchange, for the period of 2016-2018. Index kompas 100 company represent around $70-80 \%$ trillion market capitalization value of all shares listed on the Indonesian stock exchange. Market capitalization value has a meaning important for investors because it is able to influence investor's interest to make it a portfolio instrument or not. In general, the greater the market capitalization value of a stock, 
then the more investor interest in the stock, so it is suitable to be used as a population of this research and also as a reference for investors. In this population, researchers acquired 53 companies matched with the sampling criteria. The sample selection criteria were as follows:

Table 1 Sampling Criteria

\begin{tabular}{|c|l|c|}
\hline No & \multicolumn{1}{|c|}{ Criteria of Selecting The Samples } & Total \\
\hline 1. & $\begin{array}{l}\text { The companies that are listed on the index } \\
\text { kompas } 100 \text { company, respectively during the } \\
\text { period 2016-2018 }\end{array}$ & 100 \\
\hline 2. & $\begin{array}{l}\text { The companies that are not listed on the index } \\
\text { kompas 100 company, respectively during the } \\
\text { period 2016-2018 }\end{array}$ & $(35)$ \\
\hline 3. & $\begin{array}{l}\text { The companies that do not publish financial } \\
\text { statement in Indonesian Rupiah (IDR) currency. }\end{array}$ & $(5)$ \\
\hline 4. & $\begin{array}{l}\text { The companies that do not have data related to } \\
\text { research variables. }\end{array}$ & (7) \\
\hline Total of sample observation & 159 \\
\hline \multicolumn{2}{|l}{ Tear of observation } & \\
\hline
\end{tabular}

Source: Data Processed, 2020

\section{Types and samples of research}

This research is a descriptive quantitative study. The type of data used is secondary data. Population of this research were Index Kompas 100 company on Indonesia Stock Exchange (IDX), period 2016-2018. The sampling used is nonprobability sampling techniques, with the category of purposive judgment sampling. The method used in analyzing data is multiple linear regression, using the SPSS software version 21 .

\section{Research Model}

The research model used, can be seen in figure 1 as follows:

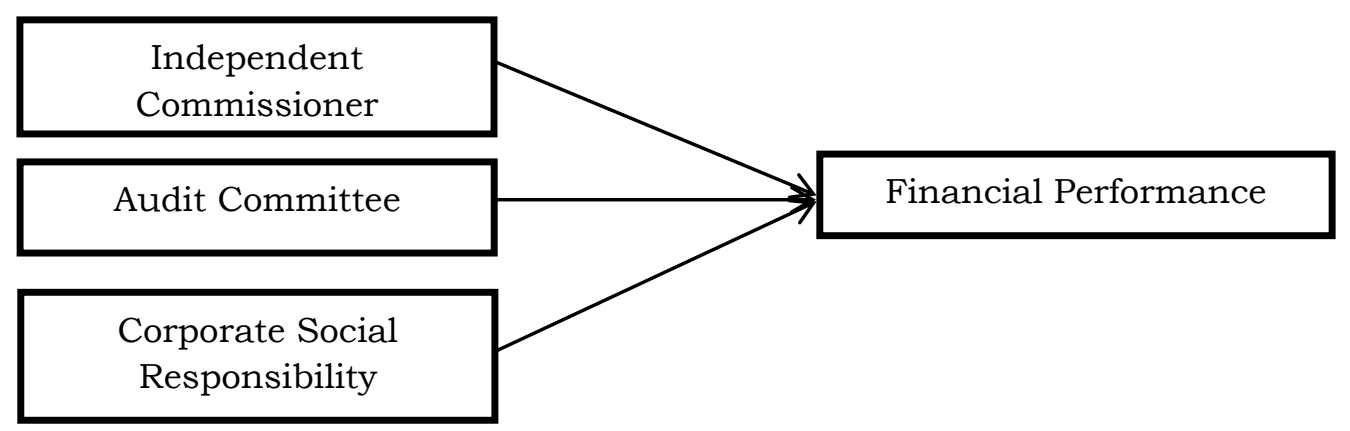

Figure 1

Research Model

\section{Operational Definition of Variable} follows:

The explanation operational definition of variable, can be seen in table 2 , as

Table 2 Definition of Research Operational Variables

\begin{tabular}{|l|l|l|l|c|}
\hline \multicolumn{2}{|c|}{ Variable } & Definition & Measurement & Scale \\
\hline $\begin{array}{l}\text { Independent } \\
\text { Variable }\end{array}$ & $\begin{array}{l}\text { Independent } \\
\text { commissioner } \\
(\mathrm{X} 1)\end{array}$ & $\begin{array}{l}\text { Independent } \\
\text { commissioners are part of } \\
\text { the board of } \\
\text { commissioners, which } \\
\text { have no relationship with } \\
\text { the company, } \\
\text { management, other } \\
\text { members of the board of }\end{array}$ & $\begin{array}{l}\text { Independent } \\
\text { commissioner }=\end{array}$ & Ratio \\
& & & \\
\hline
\end{tabular}




\begin{tabular}{|c|c|c|c|c|}
\hline \multicolumn{2}{|c|}{ Variable } & \multirow[b]{2}{*}{$\begin{array}{l}\text { Definition } \\
\text { commissioners, } \\
\text { controlling shareholders, } \\
\text { and do not have other } \\
\text { business relationships, } \\
\text { which can affect its } \\
\text { ability to act } \\
\text { independently. } \\
\text { (KNKG, 2006) }\end{array}$} & \multirow[b]{2}{*}{$\begin{array}{c}\text { Measurement } \\
\\
\text { (Mahrani \& Soewarno, } \\
\text { 2018) }\end{array}$} & \multirow[t]{2}{*}{ Scale } \\
\hline & & & & \\
\hline & $\begin{array}{l}\text { Audit } \\
\text { Committee } \\
\text { (X2) }\end{array}$ & $\begin{array}{l}\text { A person chosen by a } \\
\text { larger group to work on a } \\
\text { specific job or to perform } \\
\text { specific duties or a } \\
\text { number of board } \\
\text { members of the client's } \\
\text { company whose duty is to } \\
\text { assist the auditor in } \\
\text { maintaining its } \\
\text { independence of the } \\
\text { management. } \\
\text { (KNKG, 2006) }\end{array}$ & $\begin{array}{l}\text { Audit committee are } \\
\text { measured using the } \\
\text { number of audit } \\
\text { committee meetings } \\
\text { conducted during one } \\
\text { period }\end{array}$ & Ratio \\
\hline & $\begin{array}{l}\text { Corporate } \\
\text { Social } \\
\text { Responsibility } \\
\text { (X3) }\end{array}$ & $\begin{array}{l}\text { The responsibility of the } \\
\text { company to participate in } \\
\text { sustainable economic } \\
\text { development, in order to } \\
\text { improve the quality of life } \\
\text { and the environment, } \\
\text { which in turn will benefit } \\
\text { the company itself, and } \\
\text { society in general. } \\
\text { (The limited liability } \\
\text { companies law No. } 40 \\
\text { of 2007) }\end{array}$ & $\begin{array}{l}\text { Index GRI-G4 }= \\
\qquad \text { CSRDI }_{\mathrm{ij}}=\frac{\sum X i j}{\mathrm{Nj}}\end{array}$ & Ratio \\
\hline $\begin{array}{l}\text { Dependent } \\
\text { Variable }\end{array}$ & $\begin{array}{l}\text { Financial } \\
\text { Performance } \\
\text { (Y) }\end{array}$ & $\begin{array}{l}\text { Financial performance is } \\
\text { achievement of } \\
\text { management in running } \\
\text { the function of managing } \\
\text { the assets of the company } \\
\text { effectively during certain } \\
\text { peropde. Financial } \\
\text { performance is required } \\
\text { by the company to know } \\
\text { and evaluate to the extent } \\
\text { that the company's } \\
\text { success rate based on the } \\
\text { financial activities that } \\
\text { have been implemented } \\
\text { ( Rudianto, 2013:189) }\end{array}$ & $\begin{array}{l}\text { Tobins Q : } \\
=\frac{\text { MVS + Debt }}{\text { Total Assets }}\end{array}$ & Ratio \\
\hline
\end{tabular}

\section{FINDINGS AND DISCUSSION}

\section{Classic Assumption Test Result}

Classic assumption test reveals that, data in this study have complay the classical assumption test requirements. Test results have proven that, data is distributed with normal research, does not occur heteroskedasticity, multicholinerity, and autocorrelation. 


\section{Coefficient of Determinations Test}

Coefficient of determinations Test Result (R2) obtained the value of Adjusted $R$ Square 0.814 or $81.4 \%$. These results show that independent variables describe $81.4 \%$ of dependent variables (company's financial performance) are independent commissioner, audit committee, and corporate social responsibility, while $18.6 \%$ explained by other variables not included in this research

\section{Multiple Linear Regression Test Result} follows :

The results of multiple linear regression testing, can be seen in table 4.1, as

Table 3 Multiple Linear Regression Test Result

\begin{tabular}{|c|c|c|c|c|c|c|}
\hline \multirow{2}{*}{\multicolumn{2}{|c|}{ Model }} & \multicolumn{2}{|c|}{$\begin{array}{c}\text { Unstandardized } \\
\text { Coefficients }\end{array}$} & $\begin{array}{c}\text { Standardized } \\
\text { Coefficients }\end{array}$ & \multirow[t]{2}{*}{$\mathrm{t}$} & \multirow[t]{2}{*}{ Sig. } \\
\hline & & $\mathrm{B}$ & Std. Error & Beta & & \\
\hline \multirow{4}{*}{1} & (Constant) & -1.033 & .102 & & -10.157 & .000 \\
\hline & $\begin{array}{l}\text { Independent } \\
\text { Commissioner }\end{array}$ & 3.906 & .236 & .670 & 16.541 & .000 \\
\hline & Audit Committee & .022 & .004 & .213 & 6.105 & .003 \\
\hline & CSR & 2.768 & .388 & .285 & 7.127 & .012 \\
\hline
\end{tabular}

a. Dependent Variable: financial performance

Source : SPSS processed data output

Based on Multiple Linear Regression Test Result, then the equation, as follows :

$$
\mathrm{Y}=\mathrm{a}+\mathrm{b}_{1} \mathrm{X}_{1}+\mathrm{b}_{2} \mathrm{X}_{2}+\mathrm{b}_{3} \mathrm{X}_{3}+\mathrm{e}
$$

Thus $\mathrm{Y}=-1.033+3.906 \mathrm{X}_{1}+0,022 \mathrm{X}_{2}+2.768 \mathrm{X}_{3}+\mathrm{e}$

\section{Discussion}

\section{The effect of independent commisioner on financial performance}

Hypothesis testing results show that, independent commissioner has effect on financial performance. Independent commissioners in the company could improve supervision of management, directors and financial statements of company will also be more stringent and objective. So that management will always act according to company's objectives, it will improve financial performance. Based on the study conducted, average index kompas 100 company had complied with Financial Services Authority Regulation No.33/POJK.04/2014, that proportion independent commissioners of total at least $30 \%$ (thirty percent) of the total number of commissioners. Therefore independent commissioner is an indicator of implementation of corporate governance, because an independent commissioner performs a monitoring function to realize a company with good corporate governance, so that it will affect on financial performance.

The results of study performed by (Mahrani \& Soewarno, 2018), (Saputra, 2018), and (Bintara, 2019), which state that independent commissioner has effect on financial performance. (Mahrani \& Soewarno, 2018), independent commissioners can minimize the role of the independent commissioner is to oversee the performance of the board of directors, so that later the performance produced is in accordance with the interests of shareholders. (Saputra, 2018) show that, independent board of commissioners is the core of corporate governance assigned to ensure the implementation of corporate strategy, to maintain management in managing the company and to require the enforcement of accountability. This research of this study are different from the results of research conducted by (Zulfikar et al., 2017), (Andriana \& Panggabean, 2017) and (Farida et al., 2018) which prove that independent commissioner has no effect on financial performance. (Andriana \& Panggabean, 2017) states that the existence of an independent commissioner is only to meet the regulations set by the government. (Zulfikar et al., 2017) stated that independent commissioners cannot understand and carry out their duties as an independent party to oversee, direct, and evaluate the implementation of corporate governance. (Farida et al., 2018) stated the independent commissioner was not directly involved in operational activities. Their role is only to supervise and advise the director, most decisions are made by the director and management. 


\section{The effect of audit committee on financial performance}

Hypothesis testing results show that, audit committee has effect on financial performance. The role of the audit committee is necessary for increasing company performance, specifically in terms of supervision. The companies that have audit committees are usually more transparent in their management, so the principles of corporate governance can be applied well. In carrying out its duties, audit committee needs hold a meeting that functions as a medium of communication and coordination among its members in implementing the reporting and supervision functions of the company. Based on the study conducted, average index kompas 100 company held quite frequent audit committee meetings, so it needed to be maintained for its consistency and regularity. It shows that, the index kompas 100 company, has fulfilled Financial Services Authority Regulation NO.55/POJK.04/2015 which requires audit committee to hold regular meetings at least 1 (one) time in 3 months. During the meeting the audit committee members can discuss the latest issues faced by the company, so that the problems faced by the company can be resolved properly. By holding a meeting performed by the audit committee can prevent and decrease possibility of mistakes in making decisions by management. The audit committee often conducts meetings, which will further enhance financial performance.

This study is in line with the results of research conducted by (Aryan, 2015), (Gabriela, 2016), and (Orjinta \& Evelyn, 2018) which states that audit committee has effect on financial performance. (Aryan, 2015) stated that audit committee meetings playing necessary role to confirm the effectiveness of audit committee. Gabreila (2016) states that the more often the audit committee holds meetings will be better supervision compared to audit committees that rarely hold a meeting (considered inactive) less likely to monitor management effectively. (Orjinta \& Evelyn, 2018) stated that regular audit committee meetings can help mitigate the company's agency and information asymmetry issues, and provide fair and proper information to investors. This study are different from the result performed by (Heriyanto \& Mas'ud, 2017), and (Mulyadi, 2017), who stated that audit committee meetings had no effect on financial performance. (Mulyadi, 2017) stated that the quantity of audit committee meetings was not accompanied by quality, then frequency of audit committee meetings wil be ineffective, so that cannot affect on company's profitability. (Heriyanto \& Mas'ud, 2017) state that, even though the company implement corporate governance (one of which is by conducting audit committee meetings), it cannot improve a company's performance.

\section{The effect of corporate social responsibility on financial performance}

Hypothesis testing results show that, corporate social responsibility has effect on financial performance. Corporate social responsibility is a consideration for investors to investing in the company, and more corporate social responsibility activities that are reported will be better in the eyes of investors and prospective investors and increase the price of stocks and capital that the company also has increasingly larger. Large capital can be managed by the company, so as to make high profit and it will improve financial performance.

Based on the study conducted, average the index kompas 100 company, had implemented corporate social responsibility, even though disclosure of corporate social responsibility for each company was different. It might be cause, there were no rules regarding company criteria that were subject to corporate social responsibility obligations, what punishmenent are given to companies that violate the obligations of corporate social responsibility and how much minimum budget of corporate social responsibility costs that must be budgeted by the company (Solihin, 2008:166). Disclosure of corporate social responsibility will further enhance company's compliance in issuing sustainability reports make stakeholders easier to see development of company so that it will improve financial performance.

This study is in line with the results of research conducted by (Ummah, et al., 2016, (Mahrani \& Soewarno, 2018), and (Maqbool \& Zameer, 2018) states, corporate social responsibility has effect on financial performance. (Ummah, et al., 2016) stated that, implementation of corporate social responsibility, company will get a good image from stakeholders, company will get the trust of stakeholders, that company can be responsible for economic, environmental and social conditions of the company. (Mahrani \& Soewarno, 2018) stated that, a good relationship among community and 
company will affect the survival of the company. (Maqbool \& Zameer, 2018) stated that, corporate social responsibility can lower financial risk, so that the company has a minimum chance to experience bankruptcy, beside companies which does not implement corporate social responsibility. This study is different from the result performed by (Siregar \& Br Bukit, 2018) and (Mangantar, 2019) who stated that, corporate social responsibility had no effect on financial performance. (Mangantar, 2019) in his research stated that corporate social responsibility has no influence on financial performance. (Siregar \& Br Bukit, 2018) which states application of corporate social responsibility is only to meet the regulations set by the government.

\section{CONCLUSION AND SUGGESTIONS}

From the results of testing and analysis conducted, it can be concluded that, independent commissioner, audit committee, and corporate social responsibility have a correlation on financial performance. The existence of independent commissioners can improve oversight of the company. Audit committee through regular audit committee meetings, can prevent the possibility of error in decision making by the company. Implementation of corporate social responsibility in the company will improve the company's reputation, and for investors, implementing corporate social responsibility is an assessment of the company, in investing. Based on the above conclusion, the advice for the next researcher is: The next researcher is advised to add another variable, which can affect $s$ financial performance. The next research is suggested to use other financial ratios, in measuring financial performance. The next researcher is advised to do the research not only examine Indeks Kompas 100 company, but can be expanded in another group of companies on the Indonesia Stock Exchange.

\section{REFERENCES}

Andriana, A., \& Panggabean, R. R. (2017). The Effect of Good Corporate Governance and Environmental Performance on Financial Performance of the Proper Listed Company on Indonesia Stock Exchange. Binus Business Review. https://doi.org/10.21512/bbr.v8i1.1757

Aryan, L. A. (2015). The Relationship between Audit Committee Characteristics, Audit Firm Quality and Companies' Profitability. Asian Journal of Finance \& Accounting. https://doi.org/10.5296/ajfa.v7i2.8530

Beasly, Soctt and Brigham Eugene F. (2004). Essentials of Managerial Finance. USA : South-Western.

Bintara, Ristra. (2019). The Effect of The Mechanism of Good Corporate Governance and Company Size On Financial Performance. South East Asia Journal of Contemporary Business, Economics and Law, Vol 18. Issue 5 (April). ISSN 22891560.

Effendi, Muh Arief. (2016). The Power of Good Corporate Governance Teori dan Implementasi. Jakarta : Salemba Empat.

Fadillah, A. R. (2017). Terhadap Kinerja Perusahaan Yang Terdaftar Di Lq45. Jurnal Akuntansi.

Farida, Yuliani, N. L., \& BE, P. A. G. (2018). The Effect of Good Corporate Governance on Financial Performance in Sharia Commercial Banks in Indonesia. Prosiding Business and Economics Conference in Utilizing of Modern Technology ISSN 26229404. https://doi.org/10.2991/insyma-19.2019.15

Gabriela. (2016). The Audit Committee : Characteristic and Firm Performance : Evidance From The UK. Master in Finance : University of Porto.

Heriyanto, S., \& Mas'ud, I. (2017). Pengaruh Good Corporate Governance Terhadap Profitabilitas Perusahaan (Studi pada Perusahaan Manufaktur yang Terdaftar di 
Bursa Efek Indonesia Tahun 2012-2014). Jurnal Akuntansi Dan Keuangan Methodist.

Lako, Andreas. (2011). Dekonstruksi CSR dan Reformasi Paradigma Bisnis dan Akuntansi. Jakarta. Erlangga.

Mahrani, M., \& Soewarno, N. (2018). The effect of good corporate governance mechanism and corporate social responsibility on financial performance with earnings management as mediating variable. Asian Journal of Accounting Research. https://doi.org/10.1108/ajar-06-2018-0008

Mangantar, M. (2019). The Influence of Corporate Social Responsibility and Corporate Governance on Banking Financial Performance. European Research Studies Journal. https://doi.org/10.35808/ersj/ 1459

Maqbool, S., \& Zameer, M. N. (2018). Corporate social responsibility and financial performance: An empirical analysis of Indian banks. Future Business Journal. https://doi.org/10.1016/j.fbj.2017.12.002

McKinsey \& Company. (2002). Global Investor Opinion Survey: Key Findings. McKinsey \& Company.

Mulyadi, R. (2017). Pengaruh Karakteristik Komite Audit Dan Kualitas Audit Terhadap Profitabilitas Perusahaan. Jurnal Akuntansi.

Newell, R., \& Wilson, G. (2002). A premium for good governance. McKinsey Quarterly.

Orjinta, H. I., \& Evelyn, I. N. (2018). Effect Of Audit Committee Characteristics On Performance Of Non-Financial Firms: Evidence From A Recessed Economy. International Journal of Innovation and Applied Studies.

Rudianto, Bambang. (2013). A Corporate Social Responsibility. Bandung: Rekayasa Sains.

Saputra, M. (2018). The Influence of Independent Commissioner, Audit Committee, and Institutional Ownership on Stock Price and Its Impact on Profitability (Study at LQ45 Companies Listed on Indonesia Stock Exchange). Account and Financial Management Journal. https://doi.org/10.18535/afmj/v2i12.05

Siregar, N. B., \& Br Bukit, R. (2018). Impact of Corporate Social Responsibility and Company Size on Corporate Financial Performance with Good Corporate Governance as Moderating Variable. https://doi.org/10.2991/ebic-17.2018.37

Solihin, Ismail. (2011). Corporate Social Responsibility: From Charity to Sustainability. Jakarta: Salemba Empat.

Stiles, P. and Taylor, B. (2001). Boards at work - how directors view their roles and responsibilities. Oxford University Press, Oxford.

Zulfikar, R., May, N., Suhardjanto, D., \& Agustiningsih, S. W. (2017). Independent Commissioner Against Mandatory Disclosure of Financial Performance as a Moderating Variable. Review of Integrative Business and Economics Research.

Ummah, Nurkhasifa Khaira, Yuni Rosdiana, and Efi Fitriah. (2016). Pengaruh Pengungkapan Corproate Social Responsibility terhadap Kinerja Perusahaan Kompas 100 (Studi Empiris Perusahaan Kompas 100 di Bursa Effek Indoensia Tahun 2014-2015). Prosiding Akuntansi. ISSN : 2460-6561

Wu, MC. Lin, H.C, and Lai, C. F. (2009). The Effects of Corporate Governance on Firm Performance. Working Paper. National Changua University of Education, Changua. 